\title{
An expert-based risk ranking framework for assessing pathogens in the live baitfish trade
}

\author{
Margaret McEachran ${ }^{1}$, Fernando Sampedro Parra ${ }^{1}$, Dominic Travis ${ }^{2}$, and Nicholas Phelps $^{1}$ \\ ${ }^{1}$ University of Minnesota Twin Cities \\ ${ }^{2}$ University of Minnesota
}

May 29, 2020

\begin{abstract}
As global trade of live animals expands, there is increasing need to assess the risks of invasive organisms, including pathogens, that can accompany these translocations. The movement and release of live baitfish by recreational anglers has been identified as a particularly high-risk pathway for the spread of aquatic diseases in the United States. To provide risk-based decision support for preventing and managing disease invasions from baitfish release, we developed a hazard identification and ranking tool to identify the pathogens that pose the highest risk to wild fish via this pathway. We created a screening protocol and semi-quantitative stochastic risk ranking framework, combining published data with expert elicitation $(\mathrm{n}=25)$ and applied the framework to identify high-priority pathogens for the bait supply in Minnesota, USA. Normalized scores were developed for seven risk criteria (likelihood of transfer, prevalence in bait supply, likelihood of colonization, current distribution, economic impact if established, ecological impact if established, and host species) to characterize a pathogen's ability to persist in the bait supply and cause impacts to wild fish species of concern. The generalist macroparasite Schizocotyle acheilognathi was identified as presenting highest overall threat, followed by the microsporidian Ovipleistophora ovariae, and viral hemorrhagic septicemia virus. Our findings provide risk-based decision support for managers charged with maintaining both the recreational fishing industry and sustainable, healthy natural resources. The ranking process, implemented here for a single state case study, provides a standardized conceptual framework that could be applied across jurisdictions to inform risk-based management of the live baitfish pathway.
\end{abstract}

An expert-based risk ranking framework for assessing potential pathogens in the live baitfish trade

Running title: Expert-based ranking of pathogens in live baitfish

Authors: MC McEachran ${ }^{1,2}$, F Sampedro ${ }^{3}$, DA Travis ${ }^{2,4}$, NBD Phelps $^{1,2 *}$

* Corresponding author

${ }^{1}$ Minnesota Aquatic Invasive Species Research Center, University of Minnesota, St. Paul, MN, USA

${ }^{2}$ Department of Fisheries, Wildlife, and Conservation Biology, University of Minnesota

${ }^{3}$ Environmental Health Sciences Division, School of Public Health, University of Minnesota

4 One Health Division, Department of Veterinary Population Medicine, College of Veterinary Medicine, University of Minnesota

\section{Summary :}

As global trade of live animals expands, there is increasing need to assess the risks of invasive organisms, including pathogens, that can accompany these translocations. The movement and release of live baitfish by recreational anglers has been identified as a particularly high-risk pathway for the spread of aquatic diseases 
in the United States. To provide risk-based decision support for preventing and managing disease invasions from baitfish release, we developed a hazard identification and ranking tool to identify the pathogens that pose the highest risk to wild fish via this pathway. We created a screening protocol and semi-quantitative stochastic risk ranking framework, combining published data with expert elicitation $(n=25)$ and applied the framework to identify high-priority pathogens for the bait supply in Minnesota, USA. Normalized scores were developed for seven risk criteria (likelihood of transfer, prevalence in bait supply, likelihood of colonization, current distribution, economic impact if established, ecological impact if established, and host species) to characterize a pathogen's ability to persist in the bait supply and cause impacts to wild fish species of concern. The generalist macroparasiteSchizocotyle acheilognathi was identified as presenting highest overall threat, followed by the microsporidian Ovipleistophora ovariae, and viral hemorrhagic septicemia virus. Our findings provide risk-based decision support for managers charged with maintaining both the recreational fishing industry and sustainable, healthy natural resources. The ranking process, implemented here for a single state case study, provides a standardized conceptual framework that could be applied across jurisdictions to inform risk-based management of the live baitfish pathway.

Acknowledgements: Funding for this project was provided by the Minnesota Environment and Natural Resources Trust Fund as recommended by the Minnesota Aquatic Invasive Species Research Center and the Legislative-Citizen Commission on Minnesota Resources. We thank the 25 expert stakeholders whose participation helped to inform this study.

Conflict of interest : None of the authors or experts whose opinion was elicited in this study have a conflict of interest to declare.

Ethics approval : This research was reviewed by the University of Minnesota's Institutional Review Board and determined to be "not human research" (STUDY00007170).

Keywords : risk assessment, hazard prioritization, hazard identification, decision analysis, baitfish

\section{Introduction}

In an increasingly globalized world, there is growing evidence that trade (both formal and illegal or unregulated) of live animals and animal products is a significant driver of disease spread among wildlife populations worldwide (Daszak et al. 2000; Meyerson \& Mooney 2007; Smith et al. 2009; Hulme 2009; Daszak et al. 2000; Peeler et al. 2011; Tompkins et al. 2015). Preventing the introduction or range expansion of harmful pathogens in wildlife populations is critical, as introduced pathogens can have devastating consequences to naïve populations with potential implications for biodiversity and human health (Daszak et al., 2000; Gozlan, Peeler, Longshaw, St-Hilaire, \& Feist, 2006; Smith, Sax, \& Lafferty, 2006). The full extent to which animal trade and movement drives disease spread is unknown, but likely underestimated (Cunningham, 1996).

Recently, collaborative efforts between veterinarians, public health professionals, and conservation biologists have enhanced our toolkit for proactive characterization and management of wildlife disease risks (Cunningham, 1996; Jakob-Hoff et al., 2014). Wildlife disease risk analysis (WDRA) comprises a suite of tools and methods to characterize, communicate and mitigate the risk of disease spread via the intentional (Hartley \& Sainsbury, 2017; Pavlin, Schloegel, \& Daszak, 2009) or unintentional (G. Copp, Garthwaite, \& Gozlan, 2005) movement of live animals (OIE \& IUCN 2014; Jakob-Hoff et al. 2014). Many introduction risk analysis frameworks are largely designed for known - or at least well described - hazards (Williams, Britton, \& Turnbull, 2013) and are vulnerable to uncertainties associated with lesser-known disease agents (Gaughan, 2001). This is particularly true for invasive species and wildlife disease management, where management decisions must be made without perfect knowledge of the biological system in question (Beauvais, Zuther, Villeneuve, Kock, \& Guitian, 2019; Larson, Kueffer, \& ZiF Working Group on Ecological Novelty, 2013; Regan et al., 2005; Sainsbury \& Vaughan-Higgins, 2012). For example, disease introduction is considered one of the greatest threats posed by introduced fishes to native species (G. H. Copp, Garthwaite, \& Gozlan, 2005; Ganzhorn, Rohovec, \& Fryer, 1992). Despite this concern, and the fact that live fish have historically comprised over $90 \%$ of live animal specimens imported into the US (Smith et al. 2009; Smith et al., 2016), fish movement remains a particularly poorly understood pathway for disease spread (G. H. Copp et al., 2005; Gaughan, 
2001; Jones, 2000; Travis \& Hueston, 2000; Williams et al., 2013). Risk analyses for aquatic animals therefore involve inherent uncertainty with respect to basic disease information, disease status of wild fish populations, and the stochastic nature of biological systems (Beauvais et al., 2019; Jones, 2000; Travis \& Hueston, 2000).

The movement of live bait for use in recreational angling has been identified as a particularly high-risk and poorly understood pathway for the spread of several concerning aquatic invasive species and pathogens (e.g. viral hemorrhagic septicemia virus) (McEachran et al, in review; Boonthai et al. 2017, 2018; Mahon et al. 2018) in the Great Lakes region of the United States (Litvak \& Mandrak 1996; Ludwig \& Leitch 1996; Goodchild 2000; Drake \& Mandrak 2014). Baitfish are small fish, most commonly minnows of the family Leuciscidae (formerly Cyprinidae) (Schönhuth, Vukić, Šanda, Yang, \& Mayden, 2018; Tan \& Armbruster, 2018), that are fed as forage in aquaculture settings and are used as bait by recreational anglers. Live fish are the most popular bait in many Great Lakes states, where millions are raised on farms or harvested from the wild, moved long distances overland, and sporadically released by anglers into the water (Litvak \& Mandrak, 1993; Ludwig \& Leitch, 1996). Mandatory disease testing is limited to certain baitfish species and diseases (e.g. MN Statute 17.4991), and the health status of baitfish populations is generally poorly understood (Goodwin, Peterson, Meyers, \& Money, 2004; Jones, 2000). Pathogens typically rank among the lowest invasive species in terms of angler awareness (Cole, Keller, \& Garbach, 2016) yet are easily transferred with legal bait and can have devastating consequences if introduced (Gozlan et al., 2006; Morant et al., 2013). Consequently, the use of live baitfish presents a significant opportunity for pathogen spread. At the same time, the live baitfish industry is economically and culturally important in US states like Minnesota where demand for minnows drives a $>\$ 2.4$ million live baitfish industry and supports an even larger recreational fishing industry (United States Department of Agriculture, 2013). The sheer volume of this pathway combined with recent baitfish shortages have increased the scrutiny and demand for a safe, reliable bait supply, igniting a debate about how to balance the risk for disease spread with the value it provides to the state and the region.

Fish health researchers and aquatic resource managers are increasingly in need of a system to triage (or identify, rank, and prioritize) the large number of potential fish pathogens that could be introduced or spread via the live baitfish pathway. Although some qualitative assessments have been completed (Gunderson 2018; Boersen et al. 2017), there is no formal framework to rank pathogens in the live baitfish pathway. The purpose of this study was to develop a semi-quantitative risk ranking framework to rank pathogens in the live baitfish supply according to their potential impact on wild fish populations in Minnesota. Given the importance of the bait and fishing industries, significant uncertainty, and need for evidence-based risk management strategies (Minns \& Cooley, 2000; Stohlgren \& Schnase, 2006), multi-criteria decision analysis (MCDA) methodology was used as the basis for the risk ranking framework. MCDA enabled the integration of empirical data and value-based judgements for prioritizing hazards in the live baitfish pathway.

\section{Methods}

\section{Problem formulation and scoping}

A multi-step process centered around expert stakeholder input was designed for the risk ranking exercise (Table 1). As first step, an initial cluster of stakeholder-experts with expertise in fish health and aquatic invasive species prevention were identified from the Minnesota Department of Natural Resources (MNDNR) to provide input throughout the process and to ensure study outcomes aligned with the state management objectives.

Best practices indicate that clarifying the objective, question, or endpoint of interest is critical for the accuracy and applicability of a risk assessment (Jakob-Hoff et al., 2014). Therefore, the second step of the risk ranking exercise was to define the primary question of the analysis, which was formulated as: "What pathogens are most likely to present a risk to the health of wild fish via release of infected baitfish?" Although there is some evidence that potential human and wildlife pathogens (Mahon et al. 2018; Picco et al. 2010) may be present in live baitfish, the scope of this study was limited to pathogens of fish. After the definition of the project question, an initial list of pathogens to be assessed was obtained from ex- 
isting qualitative evaluations (Boersen et al. 2017; Gunderson 2018) and lists of important (regulatory) fish pathogens curated by the OIE (Aquatic Animal Health Code, OIE) and Minnesota law (MN Statute 17.4982). Inclusion/exclusion criteria were developed based on host susceptibility for the initial hosts, live baitfish that could be legally used in Minnesota as listed in the 2018 fishing regulations handbook (accessible at https://files.dnr.state.mn.us/rlp/regulations/fishing/fishing_regs.pdf), and the recipient population (described as "fish of concern"), which included game fish, fish listed as threatened or endangered by the Minnesota Endangered Species Statute (MN Statute 84.0895), or fish receiving management attention from MNDNR (Figure 1).

\section{Development of the risk ranking framework}

The third step of the risk ranking process was to build a framework to score the included pathogens according to defined risk criteria. A semi-quantitative matrix based on the multicriteria decision analysis (MCDA) methodology was developed to identify the high-risk fish pathogens of concern (WHO and FAO 2007; Van der Fels-Klerx et al. 2018). MCDA methodology allows for the inclusion of different types of risk information, including empirical data and expert judgement. Risk ranking criteria were developed based on previous evaluations of the bait pathway (Boersen et al., 2017; J. L. Gunderson, 2018) and adapted to reflect the likelihood of pathogen occurrence and the severity of its impact due to spreading in the baitfish pathway. The MCDA risk ranking framework was comprised of seven risk criteria: likelihood of transfer, prevalence in the bait supply, colonization potential, ecological impact if established, economic impact if established, current distribution in Minnesota, and host species. Each criterion was assigned a normalized risk score based on available literature (0-3, Table 2). An unweighted risk score (assuming equal weight among all criteria) was calculated for each pathogen by adding each individual criterion score using the following equation:

Unweighted risk score $=\sum_{i=1}^{7} S_{\mathrm{ij}}$

where $S_{i j}$ is the score for pathogen $j$ on criterion $i$. All data and calculations available in the Supporting Information.

\section{Expert opinion elicitation and pathogen scoring}

To incorporate value-based judgements into the weighting of the criteria in this assessment (Havelaar et al., 2010; Krause, 2008; Walshe \& Burgman, 2010), potential stakeholder-experts were identified based on their interest in, influence on, and valuable knowledge of the live baitfish pathway (Jakob-Hoff et al., 2014). Identified experts were then validated by eligibility criteria including: current professional position and years of experience related to fish health, aquatic invasive species, or the production of live baitfish for recreational angling. Stakeholder-experts were also asked to identify other potential participants for our study, a process called "snowball sampling", by which members of a narrowly-defined group identify other members of that group (Hald et al., 2016). Willing and informed stakeholder-experts were asked to assign a weight to each criterion such that all weights added to one (Cox, Revie, \& Sanchez, 2012; Krause, 2008). The expert weighting exercise was administered in the online survey platform Qualtrics (Qualtrics, Provo, UT 2019).

\section{Uncertainty estimation}

Three types of uncertainty were identified during the development of the risk ranking framework. First, the uncertainty associated with the criteria weights assigned by the stakeholder-experts was characterized by a Beta-PERT distribution (Vose, 2008). For each pathogen, a total weighted risk score was obtained by adding each individual risk criterion score multiplied by values from the expert's weight distribution for each criterion using the following equation (adapted from ECDC 2017):

Weighted risk score $=\sum_{i=1}^{7} W i * S_{\mathrm{ij}}(2)$

$$
W_{i} \sim \operatorname{BetaPERT}(a, b, c)
$$

where $S_{i j}$ is the score for pathogen $j$ on criterion $i$ as in Equation 1 , and $W_{i}$ is the probability distribution of the expert-designated weights for each criterion $i$. The Beta-PERT distribution was characterized by 
a minimum (a), most likely (b) and maximum value (c). Latin hypercube sampling (LHS) was performed in @Risk (Palisade, Inc.) to iterate over Equation 2 and sample stratified random numbers from each probability distribution of the expert-designated weights defined in the model (Vose, 2008). Significant correlations between input values were included in the model (Supporting Information). The LHS was repeated for 10,000 iterations to generate the final distribution of total weighted risk scores with mean and standard deviation values that accurately accounted for all possible weighted risk scores for a given set of parameters defined. Pairwise t-tests with a Bonferroni correction and nonparametric Kolmogorov-Smirnov tests (Arnold \& Emerson, 2011) were applied to test for significant differences in mean total risk scores and overall total weighted risk distributions between pathogens, respectively.

The second type of uncertainty was related to the amount of published evidence supporting the risk score assigned to each criterion. A normalized scale (0-2, Table 3) was developed to estimate the evidence uncertainty associated with the total weighted and unweighted risk scores for each pathogen. If we were unable to find published information about a particular criterion for a particular pathogen, the risk score was extrapolated from similar pathogens and was assigned a high uncertainty score (2) for that criterion. Total evidence uncertainty score for each pathogen was estimated using Equation 3:Total evidence uncertainty $=\sum_{i=1}^{7} U_{\mathrm{ij}}$ (3)

where $U_{i j}$ is the normalized uncertainty score for pathogen $j$ on criterion $i$. Total evidence uncertainty scores for each pathogen are reported in Table 4.

A third type of uncertainty was related to the 'confidence level' of the stakeholder-experts in assigning the weight values. Experts indicated their confidence in the assigned weights by a score between 1 (low) and 10 (high, integer number). The confidence scores were intended to illustrate the range and variety of confidence from various experts and not used in the final calculations of the risk ranking.

\section{Sensitivity analysis}

A sensitivity analysis was carried out to measure the impact of expert opinion value judgements on risk ranking using the tornado graph feature in @Risk to determine which expert weights had the greatest impact on overall weighted risk score for each pathogen. A positive Spearman correlation value indicated a positive relationship between the weight for that criterion and the total risk score. The criterion with the highest absolute value was identified as the most impactful risk factor for future risk management strategies.

Results

\section{Problem formulation and scoping}

A total of 33 fish pathogens were identified as potential hazards (Supporting Information). Using the inclusion/exclusion criteria established (Figure 1), pathogens were excluded due to lack of sufficient evidence for transmission in live baitfish and/or susceptibility of fish of concern. A final list of 15 pathogens were identified for the risk ranking exercise.

\section{Expert opinion elicitation and pathogen scoring}

Snowball sampling resulted in a list of 54 potential stakeholder-expert participants, of which 25 agreed to participate (Supporting Information 2). Stakeholder-experts came from a variety of backgrounds but were generally categorized as academics, government officials (both state and federal), or members of the bait and fishing industries. The industry stakeholder group $(n=4)$ reported the highest number of years of experience (mean $=30$ years, $\mathrm{sd}=14.2)$, followed by government officials $(\mathrm{n}=13, \mathrm{~m}=18, \mathrm{sd}=11.7)$, and academics $(\mathrm{n}=8$, $\mathrm{m}=17, \mathrm{sd}=10.4)$. Confidence scores generally decreased as years of experience increased. Academics had the highest average confidence score $(\mathrm{m}=6.25, \mathrm{sd}=2.12)$ followed by government officials $(\mathrm{m}=6.08, \mathrm{sd}=1.61)$ and the industry stakeholders reported the lowest overall confidence scores $(\mathrm{m}=4.5, \mathrm{sd}=1.73)$. No experts reported a conflict of interest.

Twenty-three stakeholder-experts (92\%) assigned criteria weights ranging from 0.0 to 0.5 (up to $50 \%$ weight). Two stakeholder-experts (8\%) indicated an equal weight (1/7 or 0.14 for each criterion). Beta-PERT distri- 
butions of the weightings varied in shape, indicating differences in the relative criterion's importance (weight mean value) and levels of agreement (weight standard deviation) between the experts. The criterion with the highest mean weight determined by the experts across all pathogens was "Ecological impact if established" (mean weight $=0.179)$ followed by "Colonization potential" $(\mathrm{m}=0.168)$ and "Host species" $(\mathrm{m}=0.149)$. Regarding agreement among experts (lowest standard deviation), "Prevalence" ( $\mathrm{sd}=0.065)$ was the most agreed criterion followed by "Economic impact if established" $(\mathrm{sd}=0.071)$ and "Ecological impact if established" $(\mathrm{sd}=0.078)$ (Supporting Information 2).

Unweighted risk scoring (assuming equal weight by using Eq. 1) resulted in the microsporidian parasite Ovipleistophora ovariae as the highest-risk pathogen, followed by Asian fish tapewormSchizocotyle acheilognathi and viral hemorrhagic septicemia virus (VHSV) (tied at \#2). However, multiple pathogens received the same risk score (4 pathogens with a score of 3, 3 pathogens with a score of 5 and 6 each) making it difficult to distinguish among them (Supporting Information 2). Only 7 risk ranking levels were obtained with the unweighted risk scoring system.

Weighted risk score simulations resulted in distinct distributions for the 15 pathogens evaluated (Figure $2)$. The pathogen with the highest mean risk score was Asian fish tapeworm $($ mean $=2.01, \mathrm{sd}=0.36)$, followed by Ovipleistophora ovariae (mean $=1.99, \mathrm{sd}=0.30$ ), and VHSV (mean $=1.97, \mathrm{sd}=0.40$ ) (Table 4$)$. The 'highest-concern' tier (risk scores 1.74-2.10) also included fathead minnow nidovirus (FHMNV), infectious pancreatic necrosis virus (IPNV), and the bacteria Yersinia ruckeri and Aeromonas salmonicida. The 'moderate-concern' (risk scores 1.38-1.74) included the microsporidian parasiteHeterosporis sutherlandae , golden shiner virus (GSV), and spring viremia of carp virus (SVCV). The 'lowest-concern' tier (risk scores 1.02-1.38) included white sucker bunyavirus (WSBV), fathead minnow picornavirus (FHMPV), epizootic hematopoietic necrosis virus (EHNV), the bacteria Edwardsiella ictaluri, and the macroparasiteNeascus spp. Mean risk values and overall distributions of weighted risk scores were significantly different among all pathogens by both pairwise t-tests and Kolmogorov-Smirnov tests $(\mathrm{p}<0.05)$, except for the mean risk values of IPNV and A. salmonicida( $\mathrm{p}=0.09)$. Two pairs of pathogens, including GSV and SVCV, and FHMPV and WSBV, were not significantly different from one another by either metric (Supporting Information 3). Total evidence uncertainty scores, indicating the amount of published support for assigned risk scores, ranged from 1-12 (mean=7.67) (Table 4). Uncertainty scores were generally negatively correlated with total risk scores (Figure 3a), i.e. higher-risk pathogens tended to have lower uncertainty scores; however, the relationship was not significant $(\mathrm{p}=0.14)$.

\section{Sensitivity analysis}

The impact of the expert-designated criteria weights on overall risk scores for each pathogen was examined by calculating Spearman correlation coefficients (Table 4). All of the most impactful criteria weights had a positive correlation with overall risk scores, meaning that an increase in the criteria weighting produced an increase in the overall risk score. The "host species" criteria was identified as the most impactful in the highest number of pathogens (nine pathogens). The "likelihood of transfer" and "current distribution in Minnesota" were impactful for two pathogens each, whereas the "economic impact if established" and "likelihood of colonization" were most impactful for one pathogen each.

\section{Discussion}

In this study, a MCDA risk ranking framework integrating empirical data and expert opinion was used to rank pathogens in the live baitfish pathway. Applying the framework as a case study to the problem of pathogen introduction via the Minnesota bait pathway resulted in distinct risk scores for each of the 15 pathogens assessed. The highest-risk pathogen group included the Asian fish tapeworm, O. ovariae, VHSV, FHMNV, IPNV, A. salmonicida and Y. ruckeri. To our knowledge, this is the first study that has employed both semi-quantitative scores and expert opinions to evaluate and rank pathogens in the live baitfish pathway. The inclusion of expert judgement in the risk ranking exercise allowed a more detailed ranking analysis with distinct risk scores, avoiding the risk score clustering observed in the unweighted system. The weighted framework also made explicit the impact of subjective beliefs about which criteria were most important, 
emphasizing the importance of considering value judgements when making decisions about which pathogens to manage.

The Asian fish tapeworm, O. ovariae, and VHSV were the top-ranked pathogens in both the unweighted and weighted risk scoring systems, confirming the relevance of these three fish pathogens to the bait supply pathway. The highest ranked pathogen was the non-native Asian fish tapeworm, a generalist fish parasite that can infect hundreds of fish species and known to be present in the live baitfish supply in the region (Boonthai et al. 2017; Kuchta et al. 2018). Ovipleistophora ovariae is an obligate intracellular and vertically transmitted parasite, infecting the ovarian tissue of golden shiners, leading to significant declines in fecundity by age-2 (Phelps \& Goodwin, 2008). Although O. ovariae is believed to be widely distributed and highly prevalent in the golden shiner supply chain, surveys of wild populations to confirm establishment have not been completed (McEachran et al. in review), and the parasite remains of concern. Indeed, a previous qualitative risk assessment for golden shiners imported from Arkansas bait producers identified both Asian fish tapeworm and O. ovariae as high-risk (J. L. Gunderson, 2018)(J. Gunderson, 2004).VHSV is a broadly recognized risk to fish health globally (Escobar, Escobar-Dodero, \& Phelps, 2018), and following its invasion in the Great Lakes in 2003 (Elsayed et al., 2006), has been identified as a concern in previous evaluations of the Minnesota bait industry (Boersen et al., 2017; Phelps, Craft, Travis, Pelican, \& Goyal, 2014).

The results of the risk ranking framework highlight the paradoxes of risk management efforts that focus on the host species, rather than the pathogen of interest. For example, the ranking framework identified the Minnesota certifiable diseases IPNV, A. salmonicida, and Y. ruckeri as high-risk hazards for the bait pathway. These pathogens can have serious fish health implications for salmonid species (Furones, Rodgers, \& Munn, 1993; Roberts \& Pearson, 2005; Wiklund \& Dalsgaard, 1998) and are consequently regulated in Minnesota to limit introduction and spread (MN Statute 17.4982). However, these regulations only apply to salmonid species, despite known susceptibility and evidence of at least A. salmonicida and Y. ruckeri in the local retail baitfish supply (McEachran et al, in review). In contrast, VHSV is another state-certifiable pathogen identified as high-risk in this study, but it is managed at the pathogen level, with all susceptible species (including legal bait species) subject to regulatory conditions (MN Statute 17.4991). These paradoxes highlight the importance of managing specific invasive pathogens of known risk, rather than host species, when attempting to reduce the risk of pathogen spread via any live animal movement pathway.

Estimates of evidence uncertainty varied across pathogens, with some pathogens having higher or lower uncertainty than average (Figure 3a). Some pathogens in the high-risk group (e.g. FHMNV and IPNV) and low-risk pathogens (e.g. WSBV, FHMPV) obtained high uncertainty scores, suggesting that as more information becomes available in the future, the risk ranking may change for these less well-described pathogens. Because of the high number of fish species and increasing rates of pathogen reporting and surveillance, pathogens of fish account for a large number of emerging diseases of wildlife (Tompkins et al., 2015), and so invasion management tools must be equipped to dealing with both emergent and well-documented pathogens. Fish health managers could apply the risk ranking to evaluate potential risk and determine what type of action, if any, is warranted, based on their own tolerance for uncertainty and risk (Figure 3b). If new evidence emerges in the future, the risk ranking framework can be updated and risk ranking scores recalculated, providing support for risk-based disease management.

It is important to note that while the risk ranking framework identifies pathogens of importance ('high risk') in the live baitfish supply, this does not directly translate to an inevitable impact on wild fish populations. Like all invasion scenarios, many factors must align to result in the successful establishment and negative outcome of a hazard (e.g. baitfish pathogen) to a new environment (e.g. naïve wild population of concern) (Simberloff, 2009; Stohlgren \& Schnase, 2006; Wang \& Jackson, 2011). Examples of failed introductions are impossible to quantify given the limited information for the disease status of baitfish and their movement patterns, and the disease status of wild populations. For VHSV, a pathogen where significant surveillance has occurred (i.e. Phelps et al. 2014), no detections have occurred in the Minnesota baitfish supply and therefore transmission via this pathway is presumed to be nonexistent. Evaluating the current distribution and potential for establishment of high-risk pathogens known to be in the baitfish supply (e.g. O. ovariae 
, A. salmonicida, Y. ruckeri) is warranted to better inform future risk assessments. Regardless, the risk ranking framework is a useful tool to identify and prioritize pathogens for further management consideration and provide justification for proactive prevention efforts.

Incorporating variability and uncertainty from multiple different stakeholder groups (managers, academia, and industry), and not just a single sector, is increasingly recognized as a critical part of managing invasive species (Shackleton et al., 2019). The expert opinion-based risk ranking framework developed in this study incorporates expert opinion with empirical evidence, and improves on previous qualitative evaluations and unweighted rankings to distinguish between high-, medium-, and low-risk pathogens in the live baitfish supply. Where uncertainty exists, the precautionary principle is often employed, whereby novel and highly uncertain pathogens are automatically assigned a high-priority ranking and allocated resources and risk management efforts (Larson et al., 2013; Sainsbury \& Vaughan-Higgins, 2012) This approach risks obfuscating management plans and creating burdensome regulations for producers (van Senten \& Engle, 2017). Conversely, failure to systematically assess all possible hazards may indeed overlook important pathogens, leaving fish populations at risk (Gaughan, 2001). Although the framework discussed in this study provides a relative, rather than an absolute determination of risk, disease management in the absence of a structured and inclusive process for identifying hazards could result in the over or under-inclusion of important pathogens. This framework has broad applicability for understanding risks and will provide support for difficult conservation decisions to balance invasion risks with the economic, cultural, and societal benefits associated with live baitfish use. In addition, its flexibility in application means it could be modified to assess risks in other pathways, jurisdictions, or other taxa of invasive species as invasion prevention needs emerge.

\section{Acknowledgements:}

Funding for this project was provided by the Minnesota Environment and Natural Resources Trust Fund as recommended by the Minnesota Aquatic Invasive Species Research Center and the Legislative-Citizen Commission on Minnesota Resources.

We thank the 25 expert stakeholders whose participation helped to inform this study.

\section{Conflict of interest :}

None of the authors of the manuscript or experts whose opinion was elicited in this study have a conflict of interest to declare.

\section{Ethics approval :}

This research was reviewed by the University of Minnesota's Institutional Review Board and determined to be "not human research" (STUDY00007170).

\section{Literature Cited}

Arnold, T. B., \& Emerson, J. W. (2011). Nonparametric goodness-of-fit tests for discrete null distributions. The $R$ Journal ,3 (2), 34-39.

Beauvais, W., Zuther, S., Villeneuve, C., Kock, R., \& Guitian, J. (2019). Rapidly assessing the risks of infectious diseases to wildlife species. Royal Society Open Science , 6 (1), 181043. https://doi.org/10.1098/rsos.181043

Boersen, G., Weeks, C., Phelps, N., \& Kinnunen, R. (2017).Aquatic Invasive Species Hazard Analysis for Aquaculture and Wild Harvest Bait Industry Sectors Minnesota .

Boonthai, T., Herbst, S. J., Whelan, G. E., Van Deuren, M. G., Loch, T. P., \& Faisal, M. (2017). The Asian fish tapeworm Schyzocotyle acheilognathi is widespread in baitfish retail stores in Michigan, USA.Parasites ES Vectors , 10 (1), 618. https://doi.org/10.1186/s13071-017-2541-6

Boonthai, T., Loch, T. P., Zhang, Q., Van Deuren, M. G., Faisal, M., Whelan, G. E., \& Herbst, S. J. (2018). Retail Baitfish in Michigan Harbor Serious Fish Viral Pathogens. Journal of Aquatic Animal Health , 30 (4), 
253-263. https://doi.org/10.1002/aah.10034

Cole, E., Keller, R. P., \& Garbach, K. (2016). Assessing the success of invasive species prevention efforts at changing the behaviors of recreational boaters. Journal of Environmental Management ,184 , 210-218. https://doi.org/10.1016/j.jenvman.2016.09.083

Copp, G., Garthwaite, R., \& Gozlan, R. E. (2005). Risk identification and assessment of non-native freshwater fishes: A summary of concepts and perspectives on protocols. Journal of Applied Ichthyology ,21 , 371-373. https://doi.org/10.1111/j.1439-0426.2005.00692.x

Copp, G. H., Garthwaite, R., \& Gozlan, R. E. (2005). Risk identification and assessment of non-native freshwater fishes: concepts and perspectives on protocols for the UK .

Cox, R., Revie, C. W., \& Sanchez, J. (2012). The Use of Expert Opinion to Assess the Risk of Emergence or Re-Emergence of Infectious Diseases in Canada Associated with Climate Change. PLoS ONE , 7 (7), e41590. https://doi.org/10.1371/journal.pone.0041590

Cunningham, A. A. (1996). Disease Risks of Wildlife Translocations. Conservation Biology, 10 (2), 349-353. https://doi.org/10.1046/j.1523-1739.1996.10020349.x

Daszak, P. ;, Cunningham, A. A., \& Hyatt, A. D. (2000). Emerging infectious diseases of wildlife-threats to biodiversity and human health. Science Agricultural \& Environmental Science Database Pg , 287 (5452).

Drake, D. A. R., \& Mandrak, N. E. (2014). Bycatch, bait, anglers, and roads: Quantifying vector activity and propagule introduction risk across lake ecosystems. Ecological Applications , 24 (4), 877-894. https://doi.org/10.1890/13-0541.1

ECDC. (2017). ECDC tool for the prioritisation of infectious disease threats-Handbook and Manual . https://doi.org/10.2900/723567

Elsayed, E., Faisal, M., Thomas, M., Whelan, G., Batts, W., \& Winton, J. (2006). Isolation of viral haemorrhagic septicaemia virus from muskellunge, Esox masquinongy (Mitchill), in Lake St Clair, Michigan, USA reveals a new sublineage of the North American genotype.Journal of Fish Diseases , 29 (10), 611-619. https://doi.org/10.1111/j.1365-2761.2006.00755.x

Escobar, L. E., Escobar-Dodero, J., \& Phelps, N. B. D. (2018). Infectious disease in fish: global risk of viral hemorrhagic septicemia virus. Reviews in Fish Biology and Fisheries , 28 (3), 637-655. https://doi.org/10.1007/s11160-018-9524-3

Furones, M. D., Rodgers, C. J., \& Munn, C. B. (1993). Yersinia ruckeri, the causal agent of enteric redmouth disease (ERM) in fish. Annual Review of Fish Diseases , 105-125. https://doi.org/10.1016/09598030(93)90031-6

Ganzhorn, J., Rohovec, J. S., \& Fryer, J. L. (1992). Dissemination of microbial pathogens through introductions and transfers of finfish. In A. Rosenfield \& R. Mann (Eds.), Dispersal of living organisms into aquatic systems . College Park, MD: Maryland Sea Grant Publications.

Gaughan, D. J. (2001). Disease-translocation across geographic boundaries must be recognized as a risk even in the absence of disease identification: the case with Australian Sardinops. Reviews in Fish Biology and Fisheries , 11 (2), 113-123. https://doi.org/10.1023/A:1015255900836

Goodchild, C. D. (2000). Ecological Impacts of Introductions Associated with the Use of Live Baitfish. In R. Claudi \& J. H. Leach (Eds.), Nonindigenous Freshwater Organisms: Vectors, Biology, and Impacts(pp. 181-200). CRC Press LLC.

Goodwin, A. E., Peterson, J. E., Meyers, T. R., \& Money, D. J. (2004). Transmission of Exotic Fish Viruses. Fisheries , 29 (5), 19-23. https://doi.org/10.1577/1548-8446(2004)29[19:TOEFV]2.0.CO;2 
Gozlan, R. E., Peeler, E. J., Longshaw, M., St-Hilaire, S., \& Feist, S. W. (2006). Effect of microbial pathogens on the diversity of aquatic populations, notably in Europe. Microbes and Infection ,8 (5), 13581364. https://doi.org/10.1016/J.MICINF.2005.12.010

Guidelines for Wildlife Disease Risk Analysis . (2014). Retrieved from https://portals.iucn.org/library/sites/library/files/documents/2014-006.pdf

Gunderson, J. (2004). Three-State Exotic Species Boater Survey: What do boaters know and do they care? Retrieved from http://www.seagrant.umn.edu/exotics/boat.html

Gunderson, J. L. (2018). Minnow Importation Risk Report: Assessing the risk of importing golden shiners into Minnesota from Arkansas .

Hald, T., Aspinall, W., Devleesschauwer, B., Cooke, R. M., Corrigan, T., Havelaar, A. H., .. Hoffmann, S. (2016). World Health Organization Estimates of the Relative Contributions of Food to the Burden of Disease Due To Selected Foodborne Hazards: A Structured Expert Elicitation.PLoS ONE , 11 (1). https://doi.org/https://doi.org/10.1371/journal.pone.0145839

Hartley, M., \& Sainsbury, A. (2017). Methods of Disease Risk Analysis in Wildlife Translocations for Conservation Purposes. EcoHealth ,14 (S1), 16-29. https://doi.org/10.1007/s10393-016-1134-8

Havelaar, A. H., van Rosse, F., Bucura, C., Toetenel, M. A., Haagsma, J. A., Kurowicka, D., .. Braks, M. A. H. (2010). Prioritizing Emerging Zoonoses in The Netherlands. PLoS ONE , 5 (11), e13965. https://doi.org/10.1371/journal.pone.0013965

Hulme, P. E. (2009). Trade, transport and trouble: managing invasive species pathways in an era of globalization. Journal of Applied Ecology , 46 (1), 10-18. https://doi.org/10.1111/j.1365-2664.2008.01600.x

Jakob-Hoff, R. M., Kock, R., Lees, C., Maciarmid, S. C., Miller, P. S., \& Travis, D. A. (2014). Manual of Procedures for Wildlife Disease Risk Analysis . Retrieved from World Organisation for Animal Health website: https://portals.iucn.org/library/node/43386

Jones, J. B. (2000). Baitfish and quantitative risk assessment issues.Proceedings of the OIE International Conference on Risk Analysis Aquatic Animal Health , 8-10. Paris, France.

Krause, G. (2008). Prioritisation of infectious diseases in public health - call for comments. Eurosurveillance , 13 (40), 18996. https://doi.org/10.2807/ese.13.40.18996-en

Kuchta, R., Choudhury, A., \& Scholz, T. (2018). Asian Fish Tapeworm: The Most Successful Invasive Parasite in Freshwaters. Trends in Parasitology , 34 (6), 511-523. https://doi.org/10.1016/J.PT.2018.03.001

Larson, B. M. H., Kueffer, C., \& ZiF Working Group on Ecological Novelty. (2013). Managing invasive species amidst high uncertainty and novelty. Trends in Ecology \&6 Evolution , 28 (5), 255-256. https://doi.org/10.1016/j.tree.2013.01.013

Litvak, M. K., \& Mandrak, N. E. (1993). Ecology of Freshwater Baitfish Use in Canada and the United States . 18 (12), 6-13. https://doi.org/10.1577/15488446(1993)018<0006:EOFBUI >2.0.CO;2doi.org/10.1577/1548-8446(1993)018<0006:EOFBUI $>2.0$. CO;2

Ludwig, H. R., \& Leitch, J. A. (1996). Interbasin Transfer of Aquatic Biota via Anglers' Bait Buckets. Fisheries , 21 (7), 14-18. https://doi.org/10.1577/1548-8446(1996)021<0014:ITOABV>2.0.CO;2

Mahon, A. R., Horton, D. J., Learman, D. R., Nathan, L. R., \& Jerde, C. L. (2018). Investigating diversity of pathogenic microbes in commercial bait trade water. PeerJ , 6 , e5468. https://doi.org/10.7717/peerj.5468

Meyerson, L. A., \& Mooney, H. A. (2007). Invasive alien species in an era of globalization. Frontiers in Ecology and the Environment ,5 (4), 199-208. https://doi.org/10.1890/1540-9295(2007)5[199:IASIAE]2.0.CO;2 
Minns, C. K., \& Cooley, J. M. (2000). Intentional Introductions: Are the incalculable risks worth it? In R. Claudi \& J. H. Leach (Eds.), Nonindigenous Freshwater Organisms: Vectors, Biology, and Impacts(pp. 57-59). College Park, MD.

Morant, M. P., Prpich, G., Peeler, E., Thrush, M., Rocks, S. A., \& Pollard, S. J. T. (2013). Assessment of Consequences of Notifiable Fish Disease Incursions in England and Wales. Human and Ecological Risk Assessment . https://doi.org/10.1080/10807039.2012.683726

Nathan, L. R., Jerde, C. L., Budny, M. L., \& Mahon, A. R. (2015). The use of environmental DNA in invasive species surveillance of the Great Lakes commercial bait trade. Conservation Biology , 29 (2), 430-439. https://doi.org/10.1111/cobi.12381

Pavlin, B. I., Schloegel, L. M., \& Daszak, P. (2009). Risk of importing zoonotic diseases through wildlife trade, United States. Emerging Infectious Diseases , 15 (11), 1721-1726. https://doi.org/10.3201/eid1511.090467

Peeler, E. J., Oidtmann, B. C., Midtlyng, P. J., Miossec, L., \& Gozlan, R. E. (2011). Non-native aquatic animals introductions have driven disease emergence in Europe. Biological Invasions , 13 (6), 1291-1303. https://doi.org/10.1007/s10530-010-9890-9

Phelps, N. B. D., Craft, M. E., Travis, D., Pelican, K., \& Goyal, S. M. (2014). Risk-Based Management of Viral Hemorrhagic Septicemia Virus in Minnesota. North American Journal of Fisheries Management ,34 (2), 373-379. https://doi.org/10.1080/02755947.2014.880766

Phelps, N. B. D., \& Goodwin, A. E. (2008). Vertical Transmission of Ovipleistophora ovariae (Microspora) within the Eggs of the Golden Shiner. Journal of Aquatic Animal Health , 20 (1), 45-53. https://doi.org/10.1577/H07-029.1

Picco, A. M., Karam, A. P., \& Collins, J. P. (2010). Pathogen Host Switching in Commercial Trade with Management Recommendations.EcoHealth , 7 (2), 252-256. https://doi.org/10.1007/s10393-010-0310-5

Regan, H. M., Ben-haim, Y., Langford, B., Wilson, W. G., Lundberg, P., Andelman, S. J., .. Aug, N. (2005). Robust Decision-Making under Severe Uncertainty for Conservation Management ROBUST DECISION-MAKING UNDER SEVERE UNCERTAINTY FOR. Ecological Applications ,15 (4), 14711477.

Roberts, R. J., \& Pearson, M. D. (2005). Infectious pancreatic necrosis in Atlantic salmon, Salmo salar L. Journal of Fish Diseases , 28 (7), 383-390. https://doi.org/10.1111/j.1365-2761.2005.00642.x

Sainsbury, A. W., \& Vaughan-Higgins, R. J. (2012). Analyzing Disease Risks Associated with Translocations. Conservation Biology ,26 (3), 442-452. https://doi.org/10.1111/j.1523-1739.2012.01839.x

Schonhuth, S., Vukić, J., Šanda, R., Yang, L., \& Mayden, R. L. (2018). Phylogenetic relationships and classification of the Holarctic family Leuciscidae (Cypriniformes: Cyprinoidei). Molecular Phylogenetics and Evolution, 127, 781-799. https://doi.org/10.1016/j.ympev.2018.06.026

Shackleton, R. T., Adriaens, T., Brundu, G., Dehnen-Schmutz, K., Estévez, R. A., Fried, J., .. Richardson, D. M. (2019). Stakeholder engagement in the study and management of invasive alien species. Journal of Environmental Management, 229 , 88-101. https://doi.org/10.1016/j.jenvman.2018.04.044

Simberloff, D. (2009). The Role of Propagule Pressure in Biological Invasions. Annual Review of Ecology, Evolution, and Systematics ,40 (1), 81-102. https://doi.org/10.1146/annurev.ecolsys.110308.120304

Smith, K. F., Behrens, M., Schloegel, L. M., Marano, N., Burgiel, S., \& Daszak, P. (2009). Reducing the Risks of the Wildlife Trade.Science , 324 (5927), 594-595. https://doi.org/10.1126/science.1174460

Smith, K. F., Sax, D. F., \& Lafferty, K. D. (2006). Evidence for the Role of Infectious Disease in Species Extinction and Endangerment.Conservation Biology , 20 (5), 1349-1357. https://doi.org/10.1111/j.15231739.2006.00524.x 
Stohlgren, T. J., \& Schnase, J. L. (2006). Risk analysis for biological hazards: What we need to know about invasive species. Risk Analysis , 26 (1), 163-173. https://doi.org/10.1111/j.1539-6924.2006.00707.x

Tan, M., \& Armbruster, J. W. (2018). Phylogenetic classification of extant genera of fishes of the order Cypriniformes (Teleostei: Ostariophysi). Zootaxa , 4476 (1), 6-39.

Tompkins, D. M., Carver, S., Jones, M. E., Krkošek, M., \& Skerratt, L. F. (2015). Emerging infectious diseases of wildlife: a critical perspective. Trends in Parasitology , 31 (4), 149-159. https://doi.org/10.1016/J.PT.2015.01.007

Travis, D. A., \& Hueston, W. (2000). Factors contributing to uncertainty in aquatic animal risk analysis. Proceedings of the OIE International Conference on Risk Analysis Aquatic Animal Health , 27-35. Paris, France.

United States Department of Agriculture. (2013). Census of Aquaculture .

Van der Fels-Klerx, H. J., Van Asselt, E. D., Raley, M., Poulsen, M., Korsgaard, H., Bredsdorff, L., ... Frewer, L. J. (2018). Critical review of methods for risk ranking of food-related hazards, based on risks for human health. Critical Reviews in Food Science and Nutrition , 58 (2), 178-193. https://doi.org/10.1080/10408398.2016.1141165

van Senten, J., \& Engle, C. R. (2017). The Costs of Regulations on US Baitfish and Sportfish Producers. Journal of the World Aquaculture Society , 48 (3), 503-517. https://doi.org/10.1111/jwas.12416

Vose, D. (2008). Risk Analysis: A Quantitative Guide . West Sussex, England: John Wiley \& Sons, Ltd.

Walshe, T., \& Burgman, M. (2010). A Framework for Assessing and Managing Risks Posed by Emerging Diseases. Risk Analysis ,30 (2), 236-249. https://doi.org/10.1111/j.1539-6924.2009.01305.x

Wang, L., \& Jackson, D. A. (2011). Modeling the establishment of invasive species: Habitat and biotic interactions influencing the establishment of Bythotrephes longimanus. Biological Invasions ,13 (11), 24992512. https://doi.org/10.1007/s10530-011-0071-2

Wiklund, T., \& Dalsgaard, I. (1998). Occurrence and significance of atypical Aeromonas salmonicida in non-salmonid and salmonid species: a review. Diseases of Aquatic Organisms , 32 , 49-69.

Williams, C. F., Britton, J. R., \& Turnbull, J. F. (2013). A risk assessment for managing non-native parasites. Biological Invasions , 15 , 1273-1286. https://doi.org/10.1007/s10530-012-0364-0

Tables

Table 1: Outline of the risk ranking process

\begin{tabular}{ll}
\hline Project Stage & Description \\
\hline Stakeholder identification & Identification of initial cluster of stakeholder-experts within Minnesota D \\
Problem formulation and scoping & Determination of inclusion/exclusion criteria for pathogen selection \\
Risk ranking framework development & Development of criteria and normalized risk scores \\
Expert opinion elicitation and pathogen scoring & Stochastic simulation of weighted pathogen scores based on expert-design \\
Sensitivity analysis & Spearman rank correlations to quantify the effect of subjective weight juc \\
\hline
\end{tabular}

Table 2: Description of normalized scoring scheme for risk ranking criteria.

0

Criteria

Likelihood of transfer

Prevalence in bait supply
Not likely, due to extensive testing and surveillance and strict protocols to prevent transf Has not been found in MN bait supply 
Colonization potential Current distribution in MN

Economic impact

Ecological impact if established

Host species
Not likely, organism will not be established due to climate mismatch, life cycle limitation Common, frequently encountered, widespread

No known impact on any game species, fishery, tourism or species of interest

No or negligible impact on population, community, or ecosystem ecology

No known hosts in MN or single non-game, non-threatened \& endangered (T\&E) or man

Table 3: Description of normalized scoring criteria for evidence uncertainty metric.

\begin{tabular}{ll}
\hline Score & Description \\
\hline 0 & definitive published evidence or internationally accepted conclusion \\
1 & some uncertainty or lack of definitive information in published literature + \\
2 & little or no data or information ++ \\
\hline
\end{tabular}

+: Uncertainty score automatically set at 1 for pathogens not detected in Minnesota waters or bait supply due to inherent uncertainty in disease testing unless there was significant evidence (i.e. nearly complete sampling coverage) for absence of pathogen.

++ : Uncertainty score automatically set at 2 for pathogens where no information was found.

Table 4: Results of weighted risk ranking and evidence uncertainty scoring.

\begin{tabular}{|c|c|c|c|c|}
\hline Pathogen & $\begin{array}{l}\text { Total weighted risk } \\
\text { score }(\text { mean } \pm \text { sd })\end{array}$ & Weighted rank & $\begin{array}{l}\text { Most influential } \\
\text { criterion weight } \\
\text { (Spearman rank } \\
\text { coefficient) }\end{array}$ & $\begin{array}{l}\text { Evidence } \\
\text { uncertainty score }\end{array}$ \\
\hline $\begin{array}{l}\text { Asian fish } \\
\text { tapeworm }\end{array}$ & $2.01 \pm 0.36$ & 1 & host species (0.69) & 7 \\
\hline $\begin{array}{l}\text { Ovipleistophora } \\
\text { ovariae }\end{array}$ & $1.99 \pm 0.30$ & 2 & $\begin{array}{l}\text { economic impact } \\
(0.67)\end{array}$ & 7 \\
\hline $\begin{array}{l}\text { viral hemorrhagic } \\
\text { septicemia virus }\end{array}$ & $1.97 \pm 0.40$ & 3 & host species $(0.65)$ & 4 \\
\hline $\begin{array}{l}\text { fathead minnow } \\
\text { nidovirus }\end{array}$ & $1.80 \pm 0.34$ & 4 & host species (0.75) & 10 \\
\hline $\begin{array}{l}\text { infectious } \\
\text { pancreatic } \\
\text { necrosis virus }\end{array}$ & $1.79 \pm 0.37$ & 5 & host species (0.68) & 9 \\
\hline $\begin{array}{l}\text { Aeromonas } \\
\text { salmonicida }\end{array}$ & $1.78 \pm 0.33$ & 6 & host species $(0.76)$ & 7 \\
\hline Yersinia ruckeri & $1.75 \pm 0.34$ & 7 & host species (0.75) & 6 \\
\hline $\begin{array}{l}\text { Heterosporis } \\
\text { sutherlandae }\end{array}$ & $1.67 \pm 0.37$ & 8 & host species $(0.77)$ & 5 \\
\hline $\begin{array}{l}\text { golden shiner } \\
\text { virus }\end{array}$ & $1.42 \pm 0.26$ & 9 & host species (0.64) & 11 \\
\hline $\begin{array}{l}\text { spring viremia of } \\
\text { carp virus }\end{array}$ & $1.41 \pm 0.27$ & 10 & host species (0.62) & 6 \\
\hline Neascus spp. & $1.33 \pm 0.30$ & 11 & $\begin{array}{l}\text { colonization } \\
\text { potential }(0.57)\end{array}$ & 1 \\
\hline
\end{tabular}




\begin{tabular}{|c|c|c|c|c|}
\hline Pathogen & $\begin{array}{l}\text { Total weighted risk } \\
\text { score }(\text { mean } \pm \mathrm{sd})\end{array}$ & Weighted rank & $\begin{array}{l}\text { Most influential } \\
\text { criterion weight } \\
\text { (Spearman rank } \\
\text { coefficient) }\end{array}$ & $\begin{array}{l}\text { Evidence } \\
\text { uncertainty score }\end{array}$ \\
\hline $\begin{array}{l}\text { epizootic } \\
\text { hematopoietic } \\
\text { necrosis virus }\end{array}$ & $1.15 \pm 0.38$ & 12 & $\begin{array}{l}\text { current } \\
\text { distribution }(0.67)\end{array}$ & 8 \\
\hline $\begin{array}{l}\text { fathead minnow } \\
\text { picornavirus }\end{array}$ & $1.12 \pm 0.20$ & 13 & $\begin{array}{l}\text { likelihood of } \\
\text { transfer }(0.69)\end{array}$ & 11 \\
\hline $\begin{array}{l}\text { white sucker } \\
\text { bunyavirus }\end{array}$ & $1.12 \pm 0.20$ & 14 & $\begin{array}{l}\text { likelihood of } \\
\text { transfer }(0.69)\end{array}$ & 12 \\
\hline $\begin{array}{l}\text { Edwardsiella } \\
\text { ictaluri }\end{array}$ & $1.02 \pm 0.27$ & 15 & $\begin{array}{l}\text { current } \\
\text { distribution }(0.81)\end{array}$ & 11 \\
\hline
\end{tabular}

\section{Figure Legends}

Figure 1: Inclusion criteria decision tree for pathogen selection.

Figure 2: Simulated risk score distributions for selected pathogens $(\mathrm{n}=15)$.

Figure 3: Relationship between uncertainty and risk. (A ) Summed "evidence" uncertainty scores vs. mean weighted risk scores for the 15 pathogens assessed. Total uncertainty scores were calculated according to Table 3 and Eq. 3 for each pathogen. Solid line indicates the average uncertainty score (7.6) (B ) Conceptual diagram for the theoretical risk-uncertainty-response nexus. Hypothetical thresholds for decision-making are represented by the solid line (higher risk tolerance scenario) and the dashed line (lower risk tolerance scenario).

Figure 1: Inclusion criteria decision tree for pathogen selection

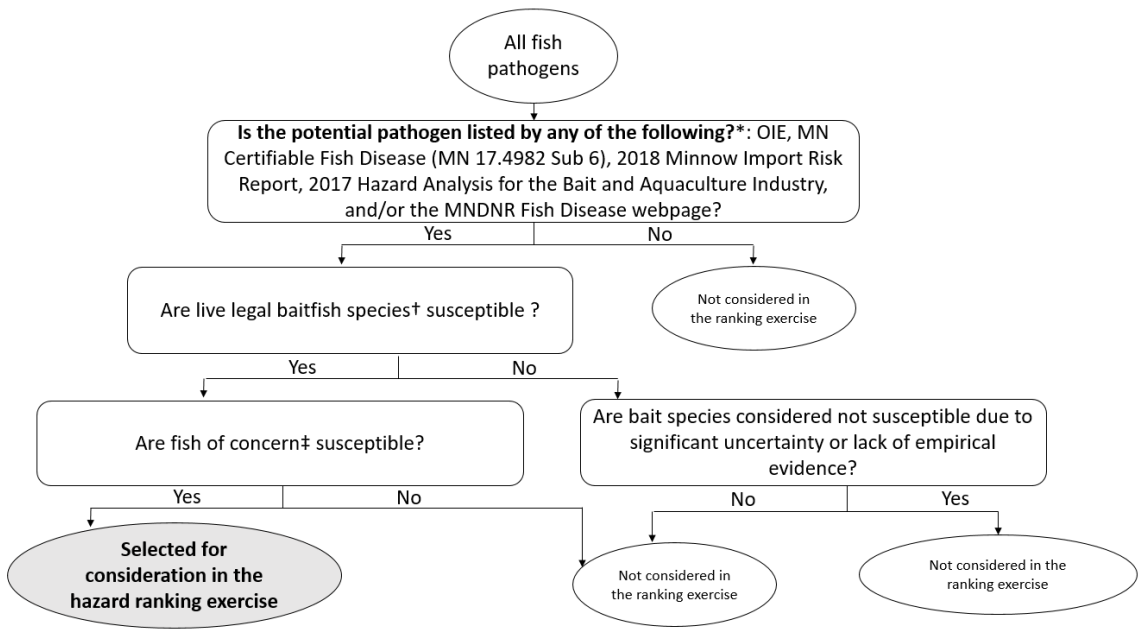

* OIE: Diseases listed by the World Organisation for Animal Health (Aquatic Animal Health Code, 2017); MN Certifiable Fish Diseases (MN Statute 17.4982); 2018 Minnow Import Risk Report (Gunderson, 2018); Hazard Analysis for Bait and Aquaculture Industry (Boersen, 2017); MNDNR Fish disease webpage (accessible at https://www.dnr.state.mn.us/fish_diseases/index.html)

+ Live legal bait species according to the 2018 Minnesota Fishing Regulations Handbook, accessible at https://files.dnr.state.mn.us/rlp/regulations/fishing/fishing_regs.pdf). Members of the minnow family, ex- 
cept carp and goldfish; bullheads, cisco (tullibee), lake whitefish, goldeyes, and mooneyes (not over 7 inches long); suckers (not over 12 inches long); mudminnows, tadpole madtoms, and stonecats. "Leeches" are designated "minnows" by the MN Fishing Regulations Handbook, but are not considered in this hazard assessment.

++ Fish of concern were defined as any fish species receiving management attention from the MNDNR, including but not limited to game species, threatened and endangered species, or species that support commercial fisheries.

Figure 2: Simulated risk score distributions for selected pathogens $(\mathrm{n}=15)$.
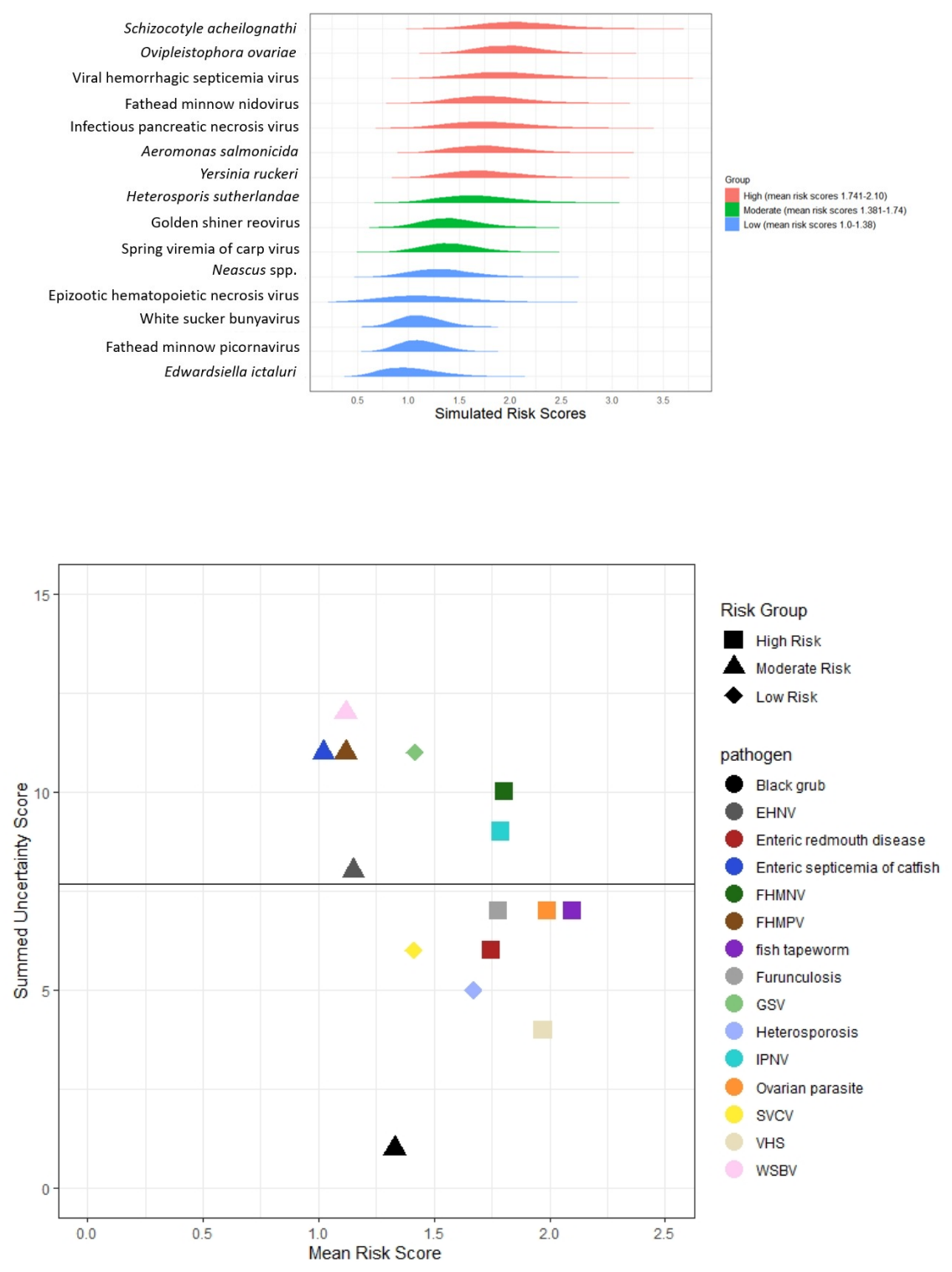

Figure 3: Relationship between uncertainty and risk. (A ) Summed "evidence" uncertainty scores vs. mean weighted risk scores for the 15 pathogens assessed. Total uncertainty scores were calculated according to 
Table 3 and Eq. 3 for each pathogen. Solid line indicates the average uncertainty score (7.6) (B ) Conceptual diagram for the theoretical risk-uncertainty-response nexus. Hypothetical thresholds for decision-making are represented by the solid line (higher risk tolerance scenario) and the dashed line (lower risk tolerance scenario).

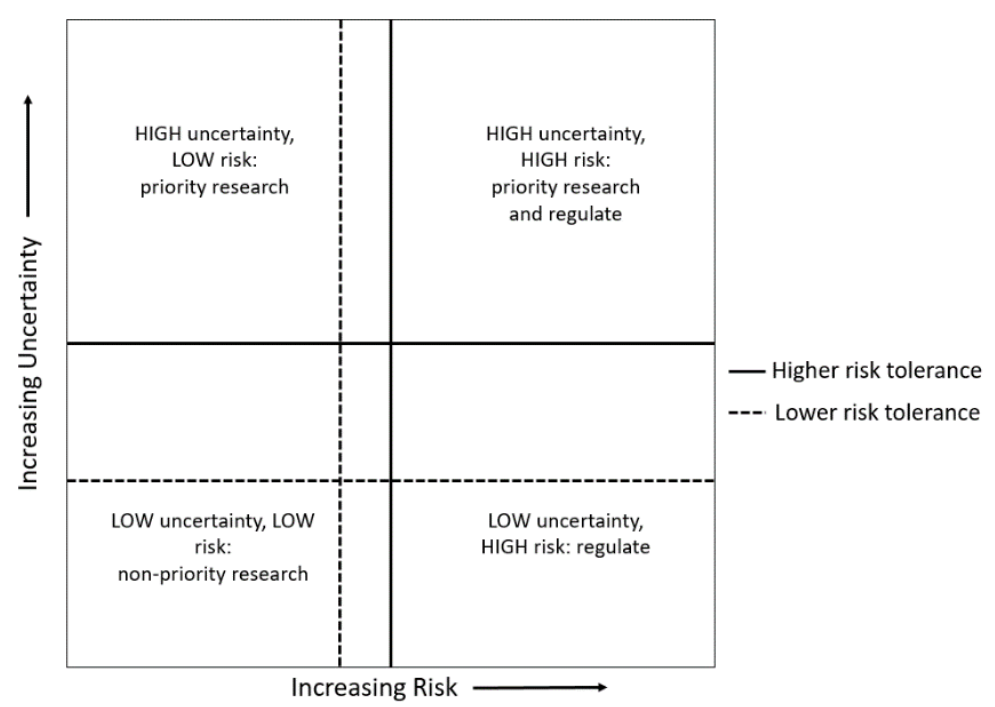

